Thorax (1958), 13, 294.

\title{
TUMOURS AND CYSTS OF THE MEDIASTINUM
}

\author{
BY
}

\author{
IAN M. MORRISON \\ From Liverpool Thoracic Surgical Centre
}

(RECEIVED FOR PUBLICATION JUNE 13, 1958)

Most mediastinal tumours and cysts follow a definite pattern due to their site of origin and the effect upon neighbouring structures of their enlargement.

A small number deviate from the usual picture, and it was felt that the examination of a large series might disclose enough of these variants to enable some contribution to be made to the basic aetiology and diagnosis of these tumours.

The present material consists of 332 cases. One hundred and sixty-six of these were investigated at the Liverpool Regional Thoracic Centre from 1941 to June, 1957, all completely verified cases being included. The other 166 cases were referred to the Tumour Registry of the Society of Thoracic Surgeons of Great Britain and Ireland between 1953 and April, 1957, by centres other than Liverpool. (The Liverpool cases referred to the Tumour Registry are included only in the first series.) The coincidence of these numbers is purely fortuitous. The Tumour Registry is selective and contains only part of the experience of British and Irish thoracic surgeons. This is evident when the percentage of thyroid tumours in the Tumour Registry series is compared with that in the Liverpool series. The diagnosis has usually been verified by excision, but sometimes by biopsy or aspiration.

The most representative picture is obtained by including all mediastinal swellings except (1) those of inflammatory and parasitic origin ; (2) metastases and direct spread from tumours elsewhere; (3) tumours of the trachea, oesophagus, heart, and great vessels.

In recent years several series of cases of tumours and cysts of the mediastinum have been reported. Some of the largest numbers have been surveyed by Blades (1946), Harrington (1949), Sabiston and Scott (1952), Burnett, Rosemond, and Bucher (1952), Peabody, Strug, and Rives (1954), Key (1954), and Ringertz and Lidholm (1956). Table I compares the distribution of cysts and tumours of
TABLE I COMPARISON OF REPORTED SERIES

\begin{tabular}{|c|c|c|c|c|c|c|c|c|}
\hline $\begin{array}{c}\text { Clas } \\
\text { of }\end{array}$ & 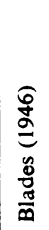 & 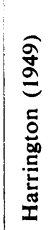 & 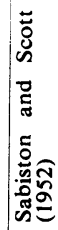 & 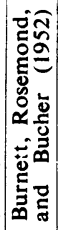 & 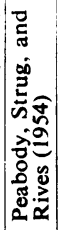 & 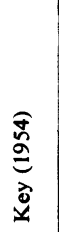 & 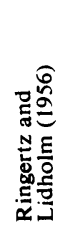 & 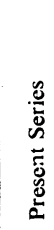 \\
\hline Cysts and & & & & & & & & \\
\hline 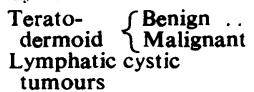 & $\begin{array}{r}14 \\
6 \\
0\end{array}$ & $\begin{array}{r}34 \\
6 \\
3\end{array}$ & $\begin{array}{l}8 \\
4 \\
0\end{array}$ & $\begin{array}{l}8 \\
2 \\
1\end{array}$ & $\begin{array}{l}5 \\
1 \\
0\end{array}$ & $\begin{array}{r}28 \\
3 \\
0\end{array}$ & $\begin{array}{r}14 \\
2 \\
7\end{array}$ & $\begin{array}{r}33 \\
3 \\
9\end{array}$ \\
\hline $\begin{array}{l}\text { Pericar } \\
\text { Endod }\end{array}$ & 10 & 7 & 2 & 6 & 4 & 4 & 6 & 13 \\
\hline$\left\{\begin{array}{r}\text { Gast } \\
\text { ent }\end{array}\right.$ & 1 & 4 & 2 & 2 & 0 & $\mathbf{0}$ & 0 & 6 \\
\hline $\begin{array}{ll}\text { Lronchogenic } & \ldots \\
\text { Non-specific cysts } & \ldots\end{array}$ & $\begin{array}{r}23 \\
0\end{array}$ & $\begin{array}{r}10 \\
8\end{array}$ & $\begin{array}{l}5 \\
5\end{array}$ & 1 & $\begin{array}{l}5 \\
0\end{array}$ & $\begin{array}{l}4 \\
0\end{array}$ & $\begin{array}{r}21 \\
4\end{array}$ & $\begin{array}{r}23 \\
6\end{array}$ \\
\hline ee & & & & & & & & \\
\hline nant & $\begin{array}{r}29 \\
1\end{array}$ & $\begin{array}{r}48 \\
3\end{array}$ & $\begin{array}{r}15 \\
5\end{array}$ & $\begin{array}{r}11 \\
7\end{array}$ & $\begin{array}{l}9 \\
8\end{array}$ & $\begin{array}{l}6 \\
4\end{array}$ & $\begin{array}{r}52 \\
6\end{array}$ & $\begin{array}{l}85 \\
16\end{array}$ \\
\hline $\begin{array}{l}\text { Benign ... } \\
\text { Malignant }\end{array}$ & $\begin{array}{l}4 \\
2\end{array}$ & $\begin{array}{l}8 \\
0\end{array}$ & $\begin{array}{r}12 \\
5\end{array}$ & $\begin{array}{l}1 \\
2\end{array}$ & $\begin{array}{l}5 \\
4\end{array}$ & 2 & 320 & $\left\{\begin{array}{l}35 \\
12\end{array}\right.$ \\
\hline nyrota & 2 & $\begin{array}{l}5 \\
0\end{array}$ & $\begin{array}{l}4 \\
1\end{array}$ & $\begin{array}{l}9 \\
1\end{array}$ & $\begin{array}{l}4 \\
0\end{array}$ & 二 & 二 & $\begin{array}{r}37 \\
6\end{array}$ \\
\hline Parathyroid $\quad$. & 0 & 0 & 2 & 0 & 0 & 0 & 0 & \\
\hline Mes & & & & & & & & \\
\hline$\left\{\begin{array}{l}\text { Benign ... } \\
\text { Malignant }\end{array}\right.$ & $\begin{array}{l}4 \\
0\end{array}$ & $\begin{array}{r}17 \\
6\end{array}$ & $\begin{array}{l}5 \\
5\end{array}$ & $\begin{array}{l}5 \\
4\end{array}$ & $\begin{array}{l}2 \\
4\end{array}$ & $\begin{array}{l}4 \\
0\end{array}$ & $\begin{array}{l}8 \\
6\end{array}$ & \\
\hline$\left\{\begin{array}{l}\text { Benign ... } \\
\text { Malignant }\end{array}\right.$ & $\begin{array}{l}4 \\
6\end{array}$ & $\overline{-}$ & $\begin{array}{r}0 \\
11\end{array}$ & $\begin{array}{l}\mathbf{0} \\
2\end{array}$ & 二 & 43 & $\begin{array}{l}0 \\
6\end{array}$ & $\begin{array}{r}4 \\
29\end{array}$ \\
\hline $\begin{array}{lll}\text { Total } & \ldots & \end{array}$ & 106 & 159 & 91 & 63 & 51 & 101 & 152 & 332 \\
\hline Unclassified cases & 3 & 9 & 10 & 16 & - & - & 3 & - \\
\hline lished & 109 & 168 & 101 & 79 & 51 & 101 & 155 & 332 \\
\hline
\end{tabular}

these authors' series with the present series. In some it has been necessary to exclude cases which do not fall within that definition of mediastinal tumour which has been used for this paper. Other authors have omitted types of tumour which are included here; thus Ringertz and Lidholm exclude thyroid tumours and several authors exclude lymphomas, although Heuer and Andrus (1940) found that lymphomas constituted $32 \%$ of all mediastinal tumours. 


\section{Anatomical Classification}

The usual anatomical subdivisions are less useful than the classification adopted by Peabody and others (1954) in which the mediastinum is divided by two planes: (1) The plane of the posterior wall of the trachea, and (2) a plane joining the manubriosternal junction to the intervertebral disc between the fourth and fifth thoracic vertebrae. The lateral boundary is the mediastinal pleura. Four compartments are, therefore, defined, namely, antero-superior, antero-inferior, posterosuperior, and postero-inferior.

Tumours and cysts as they grow encroach on more than one compartment, but it is the predominant location that is given in the subsequent sections.

\section{Pathological Classification}

The classification used is as follows :

1. Cysts and teratoid tumours

(a) Terato-dermoids

(b) Lymphatic cysts and lymphangioma

(c) Endodermal cysts

(i) Gastrogenic and enterogenous

(ii) Bronchogenic

(d) Pericardial cysts

(e) Non-specific cy'sts

2. Neurogenic tumours

3. Thymic tumours

4. Thyroid tumours

5. Parathyroid tumours

6. Mesenchymal tumours

7. Lymphoma

Table II shows the distribution of the Liverpool cases and Table III that of Tumour Registry cases by age and sex. Table IV is a combination of Tables II and III. These tables show that there is no distinctive sex pattern in the distribution of mediastinal tumours. On the other hand, in the younger age groups cysts and neurogenic tumours predominate.

TABLE II

LIVERPOOL CASES

\begin{tabular}{|c|c|c|c|c|c|c|c|c|}
\hline \multirow{2}{*}{ Type of Tumour } & \multirow{2}{*}{ No. } & \multirow{2}{*}{$\begin{array}{l}\% \text { of } \\
\text { Total }\end{array}$} & \multicolumn{2}{|c|}{ Sex } & \multicolumn{4}{|c|}{ Age Group } \\
\hline & & & $\mathbf{M}$ & $\mathbf{F}$ & $\stackrel{0}{14}$ & $\mid \begin{array}{c}15- \\
29\end{array}$ & $\begin{array}{c}30- \\
49\end{array}$ & $50+$ \\
\hline $\begin{array}{l}\text { Cysts and teratoid } \\
\text { tumours ... } \\
\text { Neurogenic tumours... } \\
\text { Thymic tumours } \ldots \\
\text { Thyroid tumours } \ldots \\
\text { Mesenchymal tumours } \\
\text { Lymphomas .. }\end{array}$ & $\begin{array}{l}47 \\
35 \\
17 \\
36 \\
5 \\
26\end{array}$ & $\begin{array}{r}28 \\
21 \\
10 \\
22 \\
3 \\
16\end{array}$ & $\begin{array}{r}27 \\
18 \\
7 \\
17 \\
4 \\
15\end{array}$ & $\begin{array}{r}20 \\
17 \\
10 \\
19 \\
1 \\
11\end{array}$ & $\begin{array}{r}9 \\
12 \\
0 \\
0 \\
0 \\
2\end{array}$ & $\begin{array}{r}15 \\
10 \\
3 \\
1 \\
0 \\
9\end{array}$ & \begin{tabular}{|r}
16 \\
7 \\
6 \\
12 \\
4 \\
11
\end{tabular} & $\begin{array}{r}7 \\
6 \\
8 \\
23 \\
1 \\
4\end{array}$ \\
\hline Total & 166 & 100 & 88 & 78 & 23 & 38 & 56 & 49 \\
\hline
\end{tabular}

\section{Cysts and Teratoid Tumours}

The distribution of this group by age and anatomical site is shown in Table V. Teratoid
TABLE III

TUMOUR REGISTRY (EXCLUDING LIVERPOOL) CASES

\begin{tabular}{|c|c|c|c|c|c|c|c|c|}
\hline \multirow{2}{*}{ Type of Tumour } & \multirow{2}{*}{ No. } & \multirow{2}{*}{$\%$} & \multicolumn{2}{|c|}{ Sex } & \multicolumn{4}{|c|}{ Age } \\
\hline & & & $\mathbf{M}$ & $\mathbf{F}$ & $\begin{array}{l}0- \\
14\end{array}$ & $\begin{array}{c}15- \\
29\end{array}$ & $\begin{array}{c}30- \\
49\end{array}$ & $50+$ \\
\hline $\begin{array}{l}\text { Cysts and teratoid } \\
\text { tumours . } \\
\text { Neurogenic tumours. } \\
\text { Thymic tumours } \\
\text { Thyroid tumours . } \\
\text { Parathyroid tumours } \\
\text { Mesenchyma! tumours } \\
\text { Lymphomas .. }\end{array}$ & $\begin{array}{r}46 \\
66 \\
30 \\
7 \\
1 \\
9 \\
7\end{array}$ & $\begin{array}{l}28 \\
40 \\
18 \\
4 \\
0 \cdot 5 \\
5 \cdot 5 \\
4\end{array}$ & $\begin{array}{r}20 \\
40 \\
13 \\
4 \\
0 \\
5 \\
3\end{array}$ & $\begin{array}{r}26 \\
26 \\
17 \\
3 \\
1 \\
4 \\
4\end{array}$ & $\begin{array}{r}9 \\
11 \\
0 \\
0 \\
0 \\
1 \\
0\end{array}$ & $\begin{array}{r}14 \\
21 \\
2 \\
0 \\
0 \\
3 \\
1\end{array}$ & $\begin{array}{r}15 \\
17 \\
14 \\
3 \\
0 \\
3 \\
4\end{array}$ & $\begin{array}{r}8 \\
17 \\
14 \\
4 \\
1 \\
2 \\
2\end{array}$ \\
\hline Total & 166 & 100 & 85 & 81 & 21 & 41 & 56 & 48 \\
\hline
\end{tabular}

TABLE IV

COMPLETE SERIES

\begin{tabular}{|c|c|c|c|c|c|c|c|c|}
\hline \multirow{2}{*}{ Type of Tumour } & \multirow{2}{*}{ No. } & \multirow{2}{*}{$\%$} & \multicolumn{2}{|c|}{ Sex } & \multicolumn{4}{|c|}{ Age Group } \\
\hline & & & $\mathbf{M}$ & $\mathbf{F}$ & $\begin{array}{l}0 \\
14\end{array}$ & $\mid \begin{array}{c}15- \\
29\end{array}$ & $\begin{array}{c}30 \\
49\end{array}$ & $50+$ \\
\hline $\begin{array}{l}\text { Cysts and teratoid } \\
\text { tumours . } \\
\text { Neurogenic tumours. } \\
\text { Thymic tumours } \\
\text { Thyroid tumours . } \\
\text { Parathyroid tumours } \\
\text { Mesenchymal tumours } \\
\text { Lymphomas . . . }\end{array}$ & $\begin{array}{r}93 \\
101 \\
47 \\
43 \\
1 \\
14 \\
33\end{array}$ & $\begin{array}{r}28 \cdot 0 \\
30 \cdot 4 \\
14 \cdot 2 \\
13 \cdot 0 \\
0 \cdot 3 \\
4 \cdot 2 \\
9 \cdot 9\end{array}$ & $\begin{array}{r}47 \\
58 \\
20 \\
21 \\
0 \\
9 \\
18\end{array}$ & $\begin{array}{r}46 \\
43 \\
27 \\
22 \\
1 \\
5 \\
15\end{array}$ & $\begin{array}{r}18 \\
23 \\
0 \\
0 \\
0 \\
1 \\
2\end{array}$ & $\begin{array}{r}29 \\
31 \\
5 \\
1 \\
0 \\
3 \\
10\end{array}$ & $\begin{array}{r}31 \\
24 \\
20 \\
15 \\
0 \\
7 \\
15\end{array}$ & $\begin{array}{r}15 \\
23 \\
22 \\
27 \\
1 \\
3 \\
6\end{array}$ \\
\hline Total .. & 332 & 100 & 173 & 159 & 44 & 79 & 112 & 97 \\
\hline
\end{tabular}

TABLE V

CYSTS AND TERATOID TUMOURS

\begin{tabular}{|c|c|c|c|c|c|c|c|c|c|}
\hline \multirow{2}{*}{ Type of Tumour } & \multirow{2}{*}{ No. } & \multicolumn{4}{|c|}{ Age Group } & \multicolumn{4}{|c|}{ Site } \\
\hline & & $\begin{array}{l}0 \\
14\end{array}$ & $\begin{array}{c}15- \\
29\end{array}$ & $\mid \begin{array}{l}30 \\
49\end{array}$ & $50+$ & AS & AI & PS & PI \\
\hline $\begin{array}{l}\text { Teratoid tumours } \\
\text { Lymphatic .. } \\
\text { Pericardial .. } \\
\text { Gastric and entero- } \\
\text { genous } \\
\begin{array}{l}\text { Bronchogenic } \\
\text { Non-specific .. }\end{array} \\
.\end{array}$ & $\begin{array}{r}36 \\
9 \\
13 \\
6 \\
6 \\
23 \\
6\end{array}$ & $\begin{array}{l}6 \\
3 \\
0 \\
5 \\
4 \\
0\end{array}$ & $\begin{array}{r}17 \\
0 \\
3 \\
1 \\
7 \\
1\end{array}$ & $\begin{array}{l}7 \\
5 \\
8 \\
0 \\
6 \\
5\end{array}$ & $\begin{array}{l}6 \\
1 \\
2 \\
0 \\
6 \\
0\end{array}$ & $\begin{array}{r}18 \\
5 \\
0 \\
0 \\
7 \\
4\end{array}$ & $\begin{array}{r}15 \\
1 \\
13 \\
0 \\
1 \\
0\end{array}$ & $\begin{array}{l}1 \\
1 \\
0 \\
6 \\
5 \\
1\end{array}$ & $\begin{array}{r}2 \\
2 \\
0 \\
0 \\
10 \\
1\end{array}$ \\
\hline Total $\ldots$ & 93 & 18 & 29 & 31 & 15 & 34 & 30 & 14 & 15 \\
\hline
\end{tabular}

Notes.-AS = antero-superior compartment. $\mathbf{A I}=$ antero-inferior compartment. $\mathbf{P S}=$ postero-superior compartment. $\quad \mathbf{P I}=$ posteroinferior compartment.

tumours and lymphatic, pericardial, and nonspecific cysts are all predominantly anterior. The age distribution offers no great diagnostic help.

Teratoid Tumours.-There were 36 of these, 23 being teratomata and 13 dermoids, i.e., teratoid tumours in which no endodermal tissues were found. Schlumberger (1951) maintains that prolonged search of apparent dermoid cysts will always show endodermal tissues, frequently pancreas. Three of the 36 cases were malignant. Rusby (1944) collected 245 cases from the literature since 1827 and added seven more; he found $11.9 \%$ to be malignant in this total of 252 . 
There is no doubt that all teratomata and dermoids should be removed. As Heuer and Andrus (1940) pointed out, not only is it often the only means of diagnosis, but many untreated patients recorded in the literature had died of complications of the disease such as haemorrhage, rupture, pressure on other organs, or malignant change. Two cases are reported in greater detail because of the unusual sites of the tumours.*

Case L.1741.-A boy of 11 years was found to have scoliosis due to fusion of congenital hemivertebrae in the upper thoracic region. He had no symptoms. A shadow was seen in the right lower chest (Fig. 1). At operation on April 29, 1946, the tumour lay between the right lower lobe and the heart and extended up the right side of the mediastinum. It was removed and shown to be a dermoid cyst containing sebaceous material.

Case L.13114. - A boy of 16 years was radiographed at the request of a National Service medical board, when a shadow was seen in the right chest (Fig. 2). On questioning, he admitted a recent pain in the right

*In these and subsequent case reports, "L" indicates a Liverpool case and "T.R." a Tumour Registry record.

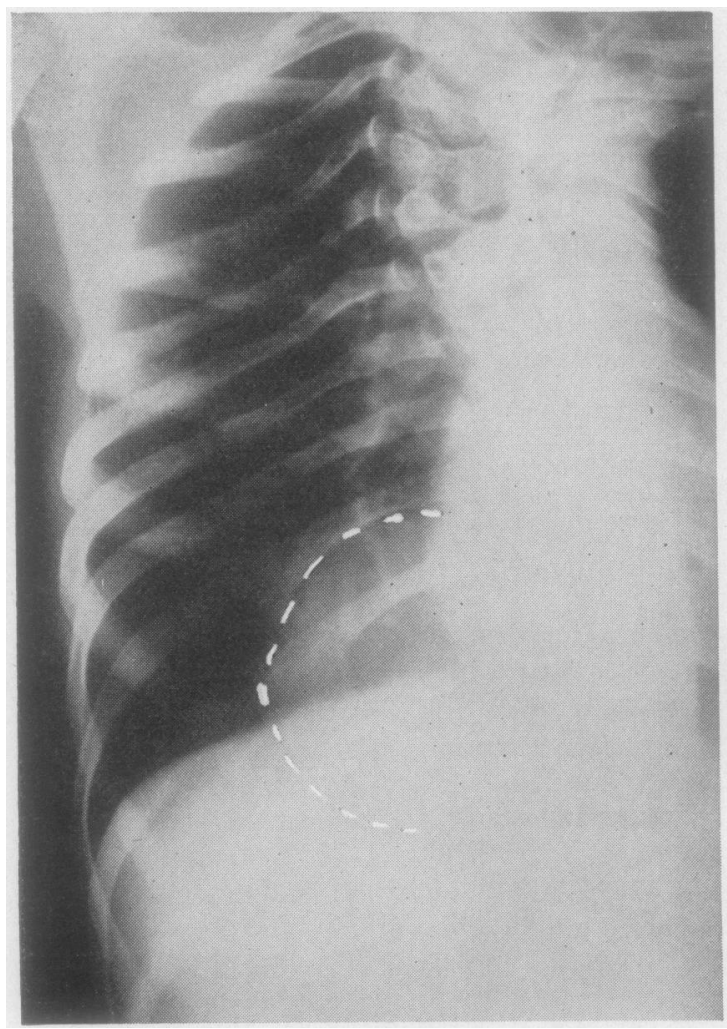

FIG. 1.-Dermoid cyst of the posterior mediastinum with congenital hemivertobrae.
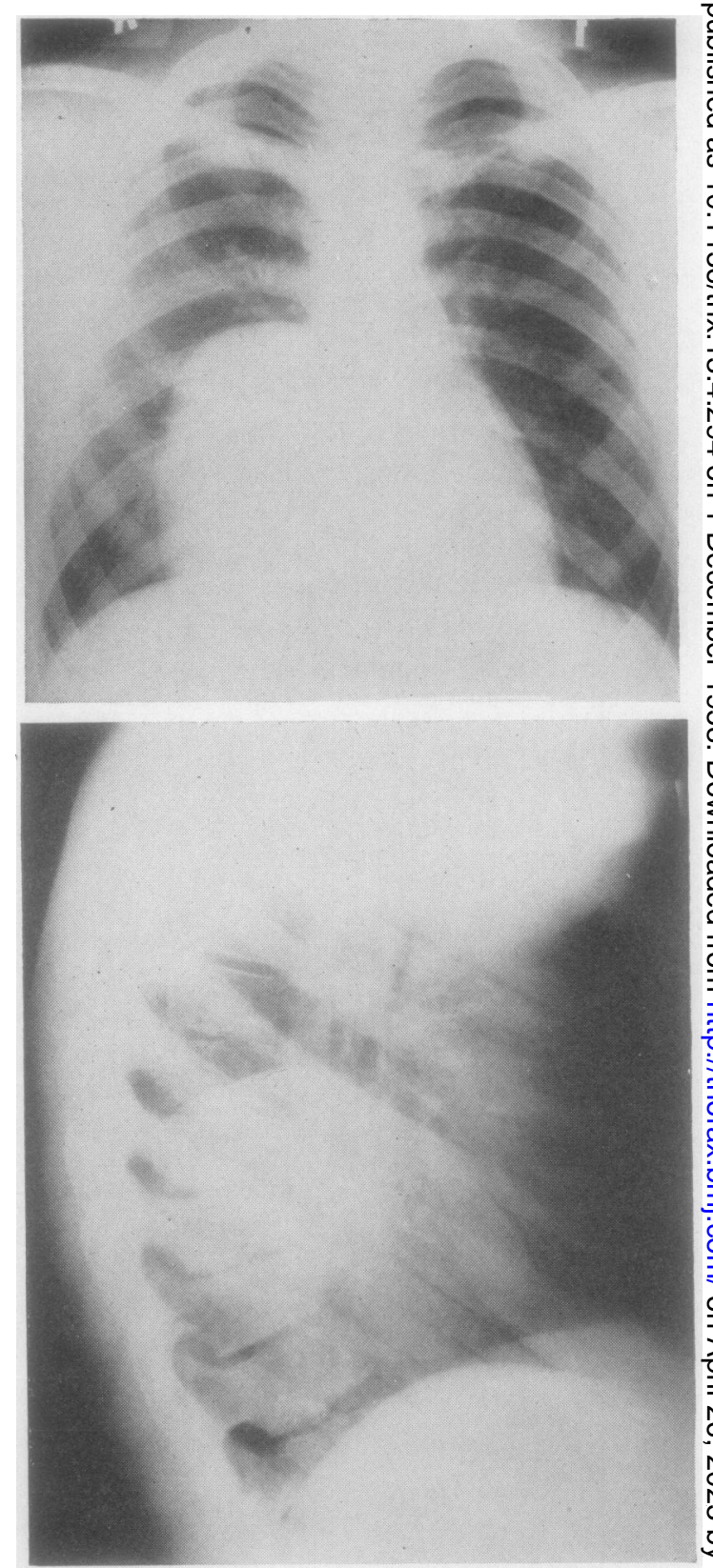

FIG. 2.-Teratoma of the posterior mediastinum.

side of his back. He had no cough or sputum. At operation on March 28, 1957, a tumour the size of a $\bar{O}$ grapefruit was found lying extrapleurally over the $\overrightarrow{\mathbb{D}}$ spine and aorta. It was removed and found to be a $\frac{\rho}{\Phi}$ trilocular cyst with solid areas containing calcifica- ¿ tion, skin, hair, adipose tissue, muscle, intestinal $\underset{x}{\sigma}$ epithelium, and brain tissue. 
The usual explanation for the occurrence of teratoid tumours in the anterior mediastinum is that they arise from cells derived from branchial remnants in common with the thymus, which originates from the third branchial pouch endoderm, and from the overlying third branchial cleft ectoderm. Hence tissues of all three dermal layers are available in the anterior mediastinum. In the first case cited, the explanation of the abnormal position is probably that the deformity of the chest led to displacement of thymic tissue, as well as other thoracic organs. In the second case, this explanation will not apply. Two other hypotheses can be put forward. The first is that this is a variety of para-oesophageal cyst which has acquired a squamous lining instead of the usual intestinal epithelium, as indeed the oesophagus itself comes to do during its development. The second hypothesis is that this teratoma arose from notochordal remnants as do teratomata of the sacrococcygeal and retropharyngeal regions. This explanation would fit a third case of posterior teratoma, which was attached to the middle third of the oesophagus of a girl of 11 (Tumour Registry case, TR.25).

Lymphatic Cystic Tumours.-These vary from the unilocular lymphatic cyst, through the multilocular cyst with septa, to the cavernous lymphangioma (Gross and Hurwitt, 1948). Childress, Baker, and Samson (1956) collected 17 cases and added one more. These cysts have a tendency to envelop the nerves and blood vessels

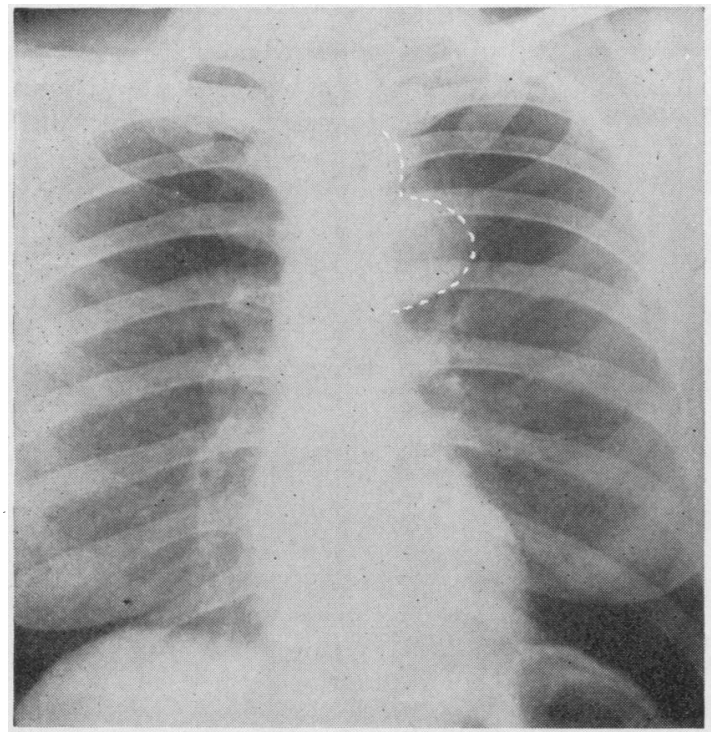

FIG. 3.-Unilocular lymphatic cyst of the anterior mediastinum.

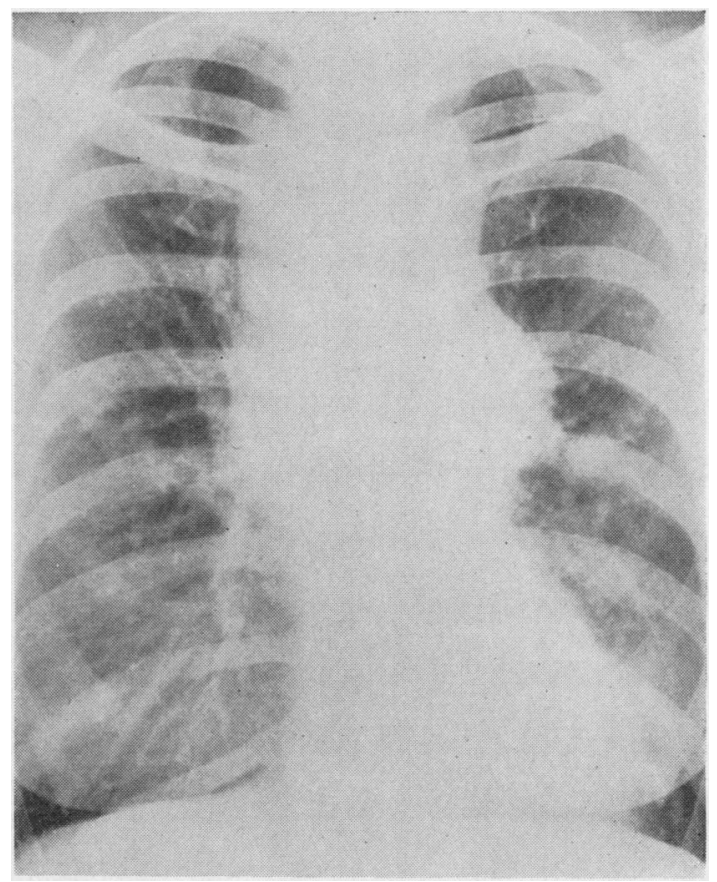

FIG. 4a

in their neighbourhood. A multilocular cyst is often called a hygroma. In this series nine cases occurred, of which two were unilocular, three multilocular, and four were lymphangiomata ; six occurred on the left side and three on the right side of the mediastinum. One occurred at the oesophageal hiatus. One case of each type is reported in greater detail.

Case L.11160.-A woman of 37 years was found at routine radiography to have an anterior mediastinal shadow (Fig. 3). Bronchoscopy was normal. At thoracotomy on October 31, 1955, a cystic swelling containing clear fluid was found lying above the aortic arch and attached to the back of the sternum. It was $10 \mathrm{~cm}$. long by $8 \mathrm{~cm}$. broad. It was necessary to excise a short length of the internal mammary artery in order to remove the cyst as the artery was completely enveloped. This was a unilocular cyst lined by cuboidal and flattened cells.

Case L.4363. - A woman of 39 years complained of cough and breathlessness. Radiography showed a tumour in the anterior mediastinum (Fig. 4). The tumour was removed and was reported on April 19. 1950 , to be " a thin-walled multi-cystic lobulated structure about $18 \times 10 \times 7 \mathrm{~cm}$. The outer and inner walls of the cystic spaces were smooth and white. Histologically the wall consisted of fibrous connective tissue with an inner lining of endothelium showing mild chronic inflammation. This was a cystic hygroma." 


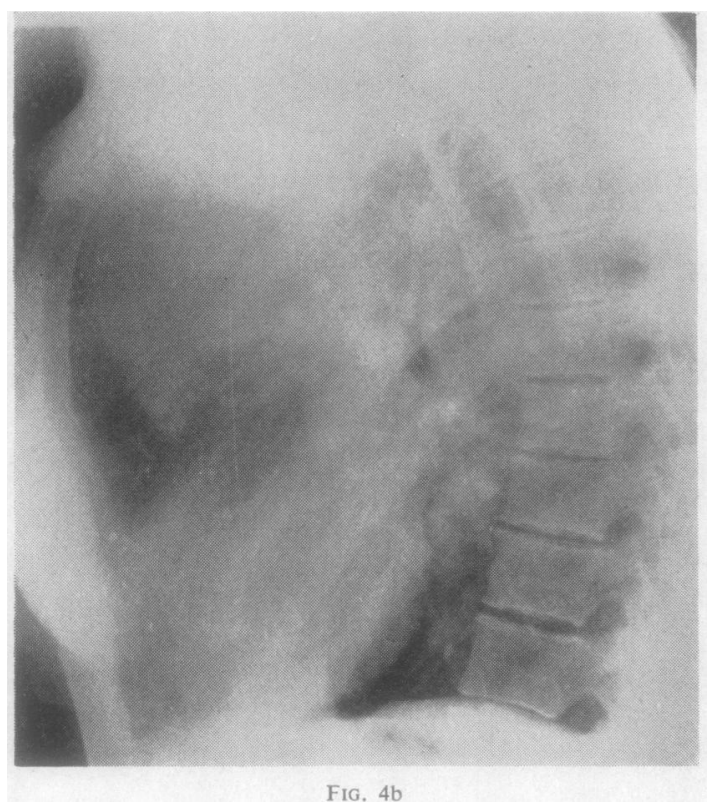

FIG. 4a and b.-Cystic hygroma of the mediastinum.

Case L.4005. - A man of 48 years had suffered from intermittent haemoptysis for eight months, and was found on radiography to have a small circular opacity high up in the left posterior mediastinum. Bronchoscopy was normal, but at thoracotomy on November 30,1949 , there was found to be a cystic swelling $3 \mathrm{~cm}$. in diameter overlying the neck of the fourth left rib and attached to the sympathetic chain. It was removed and shown to be a cavernous lymphangioma with multiple cysts presenting blood and lymph vessels in their walls. The haemoptyses continued for three years without obvious cause and then ceased. He was free of symptoms in July, 1956.

Pericardial Cysts.-Thirteen cases are included in this series ; 12 occurred on the right side and one on the left. One, on the right side, was a pericardial diverticulum.

The 11 Liverpool cases have been fully reported by Vanpeperstraete (1956). All were unilocular and single, ovoid, and from 8 to $16 \mathrm{~cm}$. in the long diameter. It must be pointed out that these were all patients who had been admitted to the Regional Thoracic Centre. Other cases have been seen as out-patients, as it is not now the practice to advise operation if a confident diagnosis can be made by aspiration. Vanpeperstraete's conclusion is that aspiration is required to confirm the diagnosis, but not operation unless doubt persists or the cyst is large and compresses neighbouring structures. He points out that some patients are unsuitable psychologically for management by observation only once an abnormal shadow has been seen on the radiograph.

Lillie, McDonald, and Clagett (1950) collected 25 cases of pericardial cyst from the literature and added 12. Of these 37,17 were on the right side and nine on the left. In 11 the site was not stated. Eight of these 37 were in fact diverticula of the pericardium because a communication with the pericardial sac was demonstrated. Mazer (1946) suggests radiography in the lateral position to allow the diverticulum to fill with pericardial fluid.

Although pericardial cysts are usually regarded as developmental in origin, they are rare in childhood (see Table V), and some authors, including Vanpeperstraete, have suggested that they may be inflammatory in nature.

Endodermal CYSTS.--These may be classed as para-oesophageal cysts, lined by gastric or enteric epithelium, and bronchogenic cysts, lined by ciliated columnar epithelium with occasional squamous cells, mucous glands, and hyaline cartilage (Schlumberger, 1951). These cysts arise from the primitive foregut, but the exact mechanism is not clear. During the sixth and seventh weeks of foetal development the oesophagus becomes stretched as the neck is differentiated from the head and thorax (Keith, 1948). The epithelium proliferates and may fill the lumen for a time. Vacuoles develop and join up so that the lumen is reconstituted. It has been suggested that some of these vacuoles join together but not to the main lumen so that a separate cyst is formed, the epithelium of which may be gastric or intestinal in type. Many other theories have been put forward, none of which accounts for the undoubted association of these cysts with vertebral anomalies, with the exception of the hypothesis of Fallon, Gordon, and Lendrum (1954). These authors ascribe the association of foregut cysts with vertebral defects to an incomplete separation of the notochord from the alimentary tract.

There is one further possibility which has not been previously put forward. This is that the splanchnic mesoderm, which is to form the oesophageal musculature, in its migration detaches part of the endodermal tube. The vertebral body centres of chondrification appear in the somites produced by segmentation of the paraxial mesoderm, which is immediately adjacent to this splanchnic mesoderm, at approximately the same stage of foetal development. A localized mesodermal fault might then reasonably lead to anomalies both of the vertebrae and of the oesophagus. Fig. 5 shows the situation diagrammatically. 


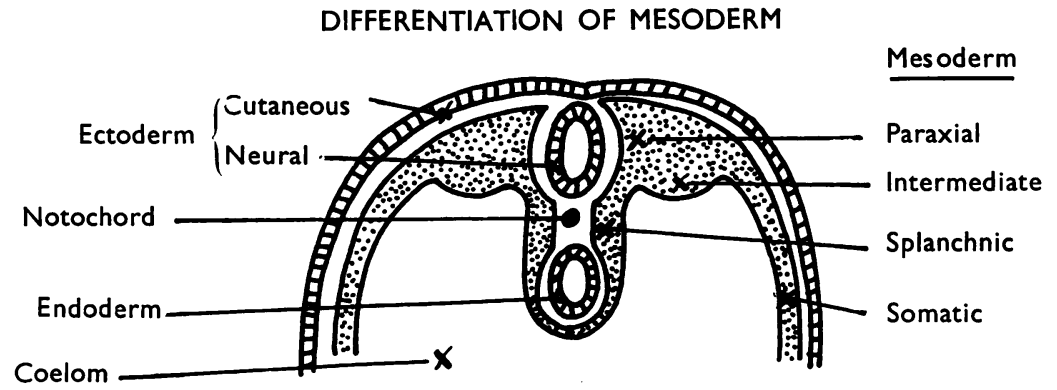

I. Early Stage

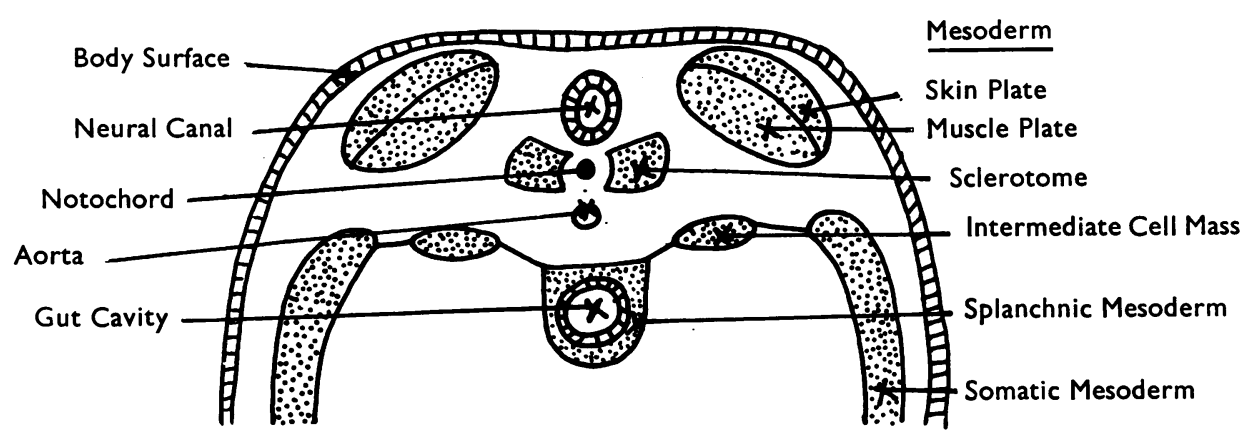

II. Later Stage

FIG. 5.-Diagram of differentiation of mesoderm.

Six cases of para-oesophageal cyst occurred in this series. They are summarized in Table VI. It will be noted that four of these six cases had vertebral anomalies. The Liverpool cases $A$ and $B$ have already been fully described by. Bickford (1949) and Sale (1953) respectively. A pre-

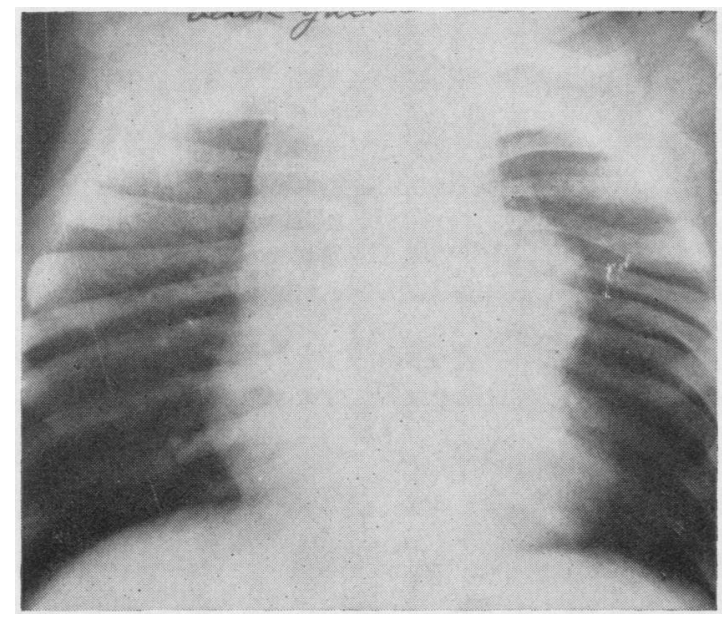

Fig. 6.-Enterogenous cyst and congenital hemivertebrae. operative radiograph of Case C is shown in Fig. 6 . The present series (five males and one female), although small in number, tends to confirm the view of Olenik and Tandatnick (1946) that the condition is commoner in males than in females.

It will be seen from Table VI that where the cyst was mid-thoracic the anomalous vertebrae were mainly upper thoracic, and where the cyst

TABLE VI

PARA-OESOPHAGEAL CYSTS

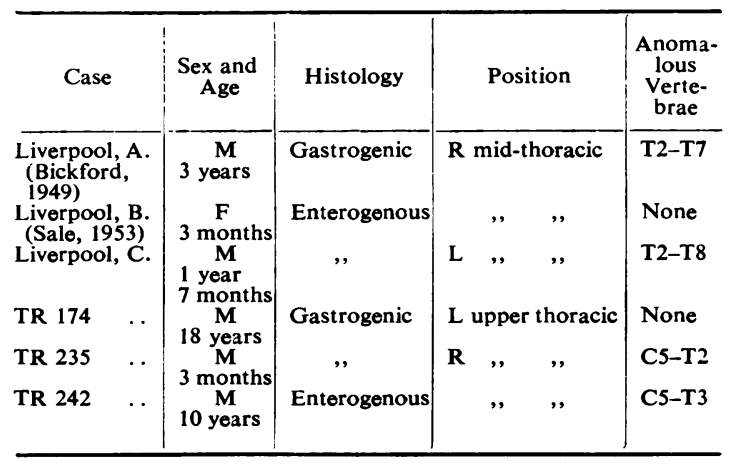


was upper thoracic the anomalous vertebrae were mainly lower cervical.

Bronchogenic cysts arise from sequestrated cells of the respiratory bud. The ciliated columnar epithelium is eventually destroyed if the cysts become infected, as they frequently do. It may then be impossible to determine their bronchogenic nature, and they have to be classified with the non-specific cysts. Thirteen patients were males and 10 females. The age range was 8 months to 67 years.

Fourteen cases of bronchogenic cyst had symptoms, often cough, dyspnoea, and chest pain. If the classification of Maier (1948) is used, the sites were :

\begin{tabular}{|c|c|c|}
\hline Paratracheal & .. & \\
\hline Carinal ... & $\ldots$ & $\ldots$ \\
\hline Hilar & $\ldots$ & $\ldots$ \\
\hline Para-oesophageal & $\cdots$ & $\cdots$ \\
\hline Miscellaneous $\ldots$ & $\ldots$ & $\ldots$ \\
\hline
\end{tabular}

The essential unity of the endodermal group of cysts is illustrated by one case (TR.416) where a bronchogenic cyst was removed from the right paratracheal region; after nine months an enterogenous cyst of the mesentery caused intestinal obstruction.

Non-SPECIFIC CYSTS.-These were cysts in which the lining was columnar epithelium or granulation tissue. The wall was fibrous or collagenous. Five of the six patients were women over 30 years of age. The cysts were discovered on routine radiography and the sites varied from the anterior mediastinum superiorly to the neighbourhood of the sympathetic chain inferiorly. It is probable that these cysts are the end-result of inflammation and haemorrhage occurring in cysts of bronchogenic, dermoid, or lymphatic type.

\section{Neurogenic Tumours}

The 101 neurogenic tumours of the mediastinum are classified according to the system of Schlumberger (1951).

\section{Tumours of Nerve Fibres}

(a) Neurilemmoma $=$ neurinoma $=$ tumours of the nerve sheath of Schwann

(b) Neurofibroma, lacking the orderly arrangement of $(a)$

(c) Neurosarcoma, with areas of palisading and other areas of poor differentiation

\section{Tumours of Nerve Cells}

(a) Ganglioneuroma

(b) Neuroblastoma

Intermediate tumours exist, with both ganglion cells and neuroblastomatous elements. Ringertz
TABLE VII

NEUROGENIC TUMOURS

\begin{tabular}{|c|c|c|c|}
\hline Classification of Tumour & $\begin{array}{l}\text { Ringertz } \\
\text { and } \\
\text { Lidholm } \\
\text { (1956) }\end{array}$ & $\begin{array}{l}\text { Ackerman } \\
\text { and } \\
\text { Taylor } \\
\text { (1951) }\end{array}$ & $\begin{array}{c}\text { Present } \\
\text { Series }\end{array}$ \\
\hline $\begin{array}{lll}\begin{array}{l}\text { Neurilemmoma .. } \\
\text { Neurofibroma } \ldots\end{array} & \ldots & \ldots \\
\text { Neurosarcoma } \ldots & \ldots & \ldots \\
\begin{array}{l}\text { Ganglioneuroma } \\
\text { Neuroblastoma . . }\end{array} & \ldots & \ldots \\
\begin{array}{l}\text { Sympathicoblastoma } \\
\text { Paraganglioma, benign }\end{array} & \ldots & \ldots \\
\text { malignant } & \ldots \\
\begin{array}{l}\text { Pheochromocytoma, benign } \\
\text { malignant }\end{array}\end{array}$ & \} $\begin{array}{r}38 \\
4 \\
14 \\
0 \\
2 \\
0 \\
0 \\
0 \\
0\end{array}$ & $\begin{array}{r}20 \\
7 \\
4 \\
7 \\
10 \\
0 \\
0 \\
0 \\
0 \\
0\end{array}$ & $\begin{array}{r}33 \\
18 \\
5 \\
31 \\
8 \\
1 \\
3 \\
1 \\
0 \\
1\end{array}$ \\
\hline Total ... & 58 & 48 & 101 \\
\hline$\left\{\begin{array}{l}\text { Benign } \\
\text { Malignant } \\
\text { Malignant }\end{array}\right.$ & $\begin{array}{c}52 \\
6 \\
10 \cdot 3\end{array}$ & $\begin{array}{c}41 \\
7 \\
14 \cdot 6\end{array}$ & $\begin{array}{l}85 \\
16 \\
15 \cdot 8\end{array}$ \\
\hline
\end{tabular}

and Lidholm (1956) found three such cases to have a benign prognosis. On the other hand, Ackerman and Taylor (1951) had seven such patients, of whom one died post-operatively and three developed fatal metastases. This was also the result in the only case in the present series. In Table VII the cases of Ringertz and Lidholm have been classified as ganglioneuroma and those of other series as neuroblastoma.
(c) Sympathicoblastoma
(d) Paraganglioma
(e) Phaeochromocytoma

The distribution of the 101 cases is compared with the series of Ringertz and Lidholm and of Ackerman and Taylor in Table VII. It will be seen that the percentage of malignant tumours is similar to that of the latter authors' series. Burnett and others (1952) had seven malignant cases in a total of 18 , or $39 \%$. Of the present series 57 were male and 44 female. Twenty-three were aged $0-14,31$ aged $15-29,24$ aged $30-49$, and 23 aged 50 or more. Seven of the 16 patients with malignant tumours were under the age of 15 ; in other words, seven of the 23 neurogenic tumours in patients under the age of 15 were malignant, or $30.4 \%$. Ellis and DuShane (1956) reported five out of 19 or $26.3 \%$ malignant in this age group.

Twelve of the neurogenic tumours had extensions through the intervertebral foramen. In eight of these cases the extension was small, and it was possible to remove it by the thoracic route with the main tumour. In the other four cases a separate spinal operation was required. It is a considerable advantage in such cases to perform a combined operation with a neurosurgeon. These 12 tumours were neurilemmoma (4), neuro- 


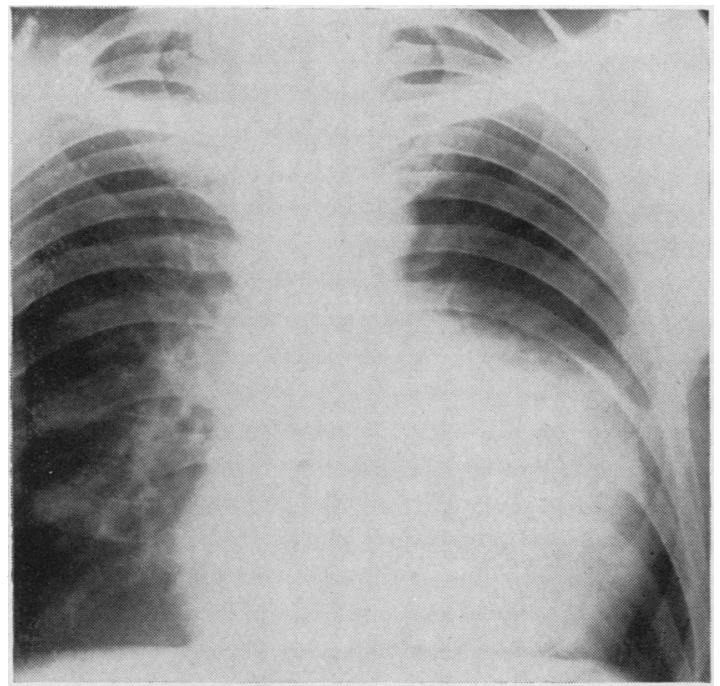

terior tumours, 65 were in the superior compartment. Hirschfeld (1951) found $77 \%$ in this compartment. Anterior neurogenic tumours have been reported by Kent, Blades, Valle, and Graham (1944), who had five anterior out of 93 collected neurogenic tumours, and by Key (1954), who had one case.

Of the 18 neurofibromas, four had the cutaneous stigmata of Von Recklinghausen's disease, and in two others there were multiple intrathoracic nerve tumours. One of these is reported more fully.

Case L.8552.-Routine radiography of an R.A.F. corporal aged 24 years disclosed a left paravertebral shadow with some rib abnormalities (Fig. 8). He was symptom free and had no skin tumours or pigmented areas. Barium swallow showed no displacement of the oesophagus, and the tumour did not pulsate. Vertebral films were normal. Thoracoscopy revealed a lobular mass beneath the mediastinal pleura paravertebrally, tapering to a point at each

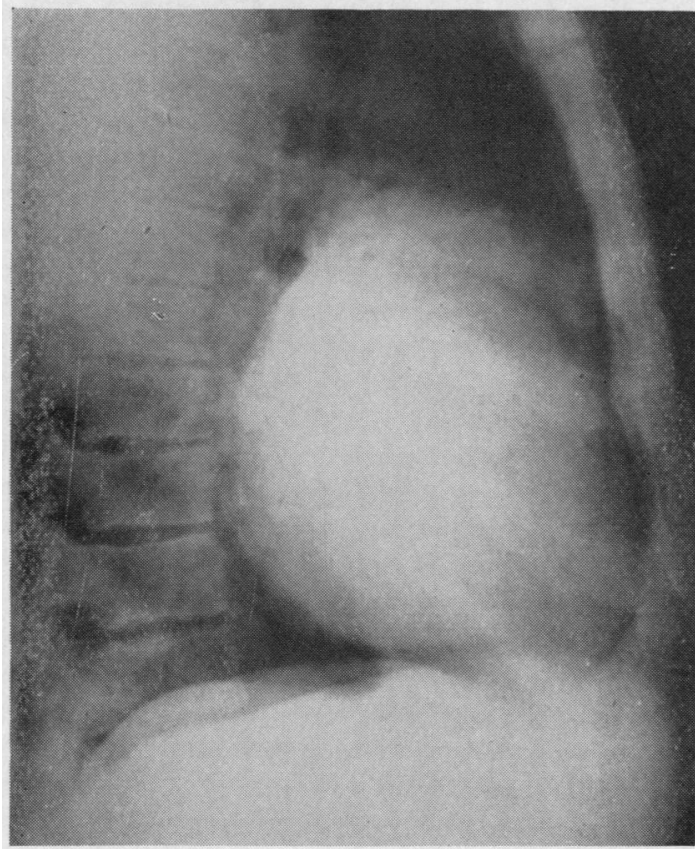

FIG. 7.-Neurofibroma of anterior mediastinum.

fibroma (3), ganglioneuroma (3), neuroblastoma (1), and chromaffinoma (1), showing that any histological type may have an intervertebral extension.

Three of the 101 tumours were in the anterior mediastinum. Fig. 7 shows one of these, a neurofibroma. The others were a neurilemmoma and a malignant phaeochromocytoma. Of the 98 posend. Lumbar puncture was normal. At operation on October 30, 1953, a large number of nodular tumours were found beneath the latissimus dorsi and on the surfaces of the fifth to seventh ribs and intercostal muscles. These were all excised. The fifth rib was resected and the chest opened. An elongated tumour lay in the position of the sympathetic chain with extensions along the fifth and sixth intercostal nerves. No intraspinal extension was present. The tumour was completely removed and has not recurred. Dr. Whitwell reported that it was "a firm lobulated whitish mass about $15 \mathrm{~cm} . \times 1-2 \mathrm{~cm}$. It had several branches $2-3 \mathrm{~cm}$. long similar to the main trunk.

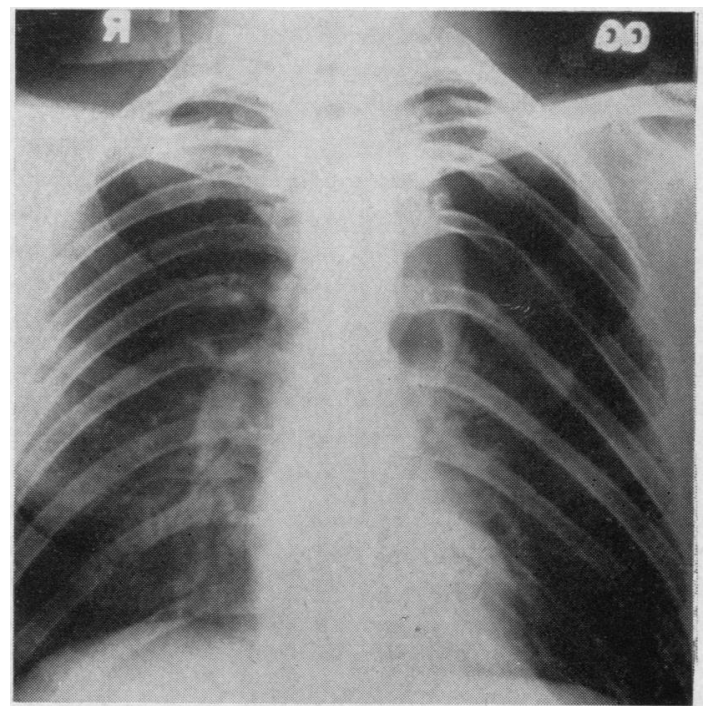

Fig. 8.-Plexiform neurofibroma, the postero-anterior view showing:a paravertebral tumour and splaying of the ribs, by, intercostal extensions. 
The cut surface was shiny and white. Microscopically, this tissue was fairly homogeneous and had the structure of a plexiform neuroma, a variety of Von Recklinghausen's disease." The extrathoracic and intercostal nerve tumours were identical with the main tumour.

Chromaffin Cell Tumours.-Schlumberger (1951) defines " paraganglioma" as a hormonally inactive tumour arising from chromaffin cells associated with the visceral sympathetic ganglia, and "phaeochromocytoma" as the hormonesecreting tumour of these cells. Brines and Jennings (1948) describe "chromaffin" as a misnomer, since the reaction is not specific to chromates but occurs when any strong oxidizing agent acts on epinephrine and related substances. "Chemodectoma" has been preferred by some authors as a name for paraganglioma without hormone secretion.

Phaeochromocytoma of the mediastinum causes the syndrome of paroxysmal hypertension as it does when situated in the suprarenal medulla or elsewhere. One Tumour Registry case, a boy of 17 years, presented in this way and was found to have metastases.

Schlumberger found only one hormonally inactive paraganglioma in the literature, the case of Miller (1924), which arose in the right paravertebral region near the sixth rib. Since he wrote five more have been reported. Godwin, Watson, Pool, Cahan, and Nardiello (1950) found one in the left upper posterior mediastinum of a man of 52 years. Duncan and McDonald (1951) had two cases arising in the right paravertebral region. McDonald, Aufderheide, and Fuller (1954) removed one from the upper thoracic and lower cervical region through a neck incision. Shaw and Kennedy's case (1956), a man of 30 years, had such a tumour in the left paravertebral region opposite the ninth intercostal space.

Other cases have been described where a chemodectoma arose from the chemoreceptor bodies of the aortic arch and pulmonary artery. Although probably related tumours, these do not conform to the definition of Schlumberger cited above for paraganglioma.

The present series includes three benign and one malignant paraganglioma. In some tomographic films the paravertebral shadow was noticeably fusiform in shape and this may be a diagnostic feature.

Fig. 9 shows a left paravertebral tumour in a boy of 18 years. The eighth intercostal space and intervertebral foramen were demonstrably widened. At operation on October 10, 1952, the tumour was
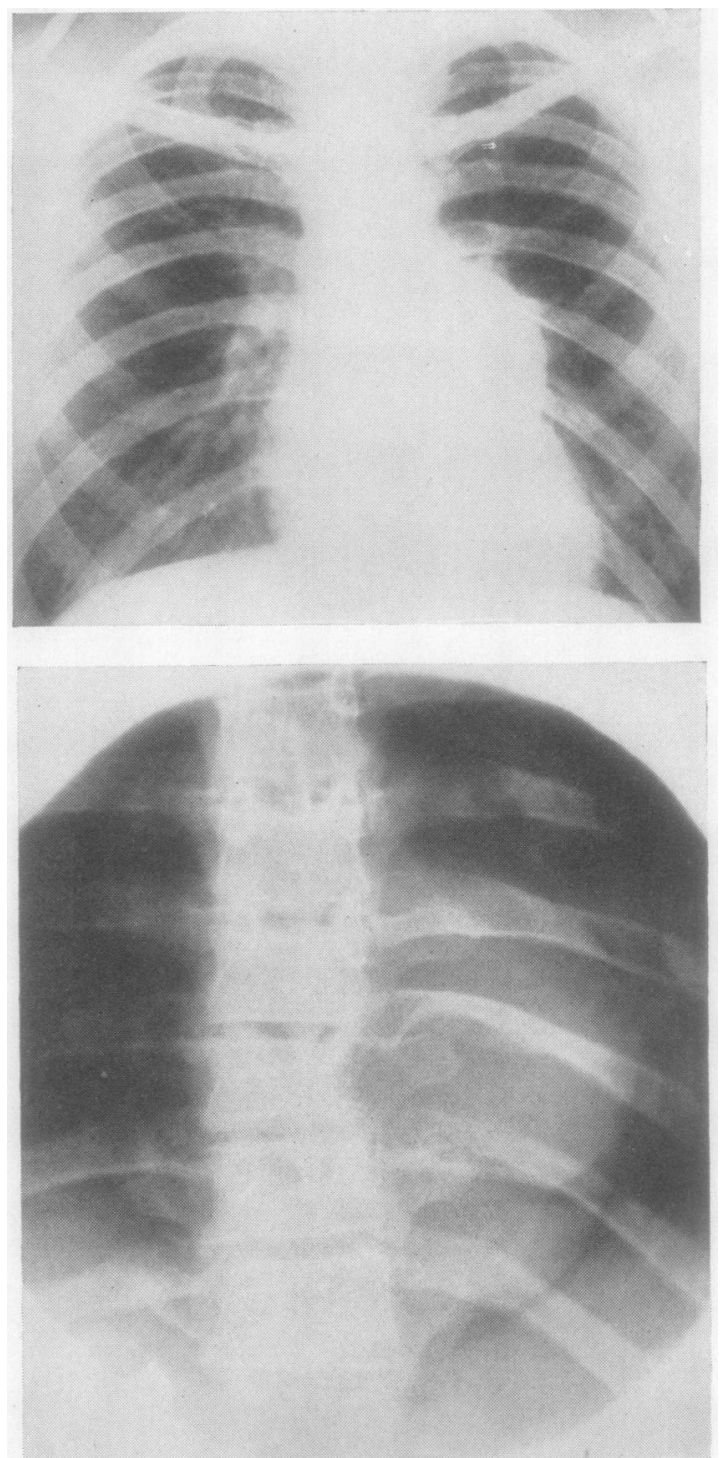

FIG. 9.-Benign chromaffinoma. Postero-anterior view of the chost and a spinal film showing spindle-shaped tumour.

removed with its intervertebral extension, a hole in the dura mater requiring suture. His recovery was uninterrupted. The specimen became brown after immersion in formal saline. Microscopically it was a benign chromaffinoma.

The other benign cases were in a boy of 19 years where the tumour lay in the left paravertebral region opposite the fourth and fifth ribs, and a man of 23 years with a right paravertebral tumour opposite the sixth and seventh ribs. The malignant chromaffinoma is reported more fully. 


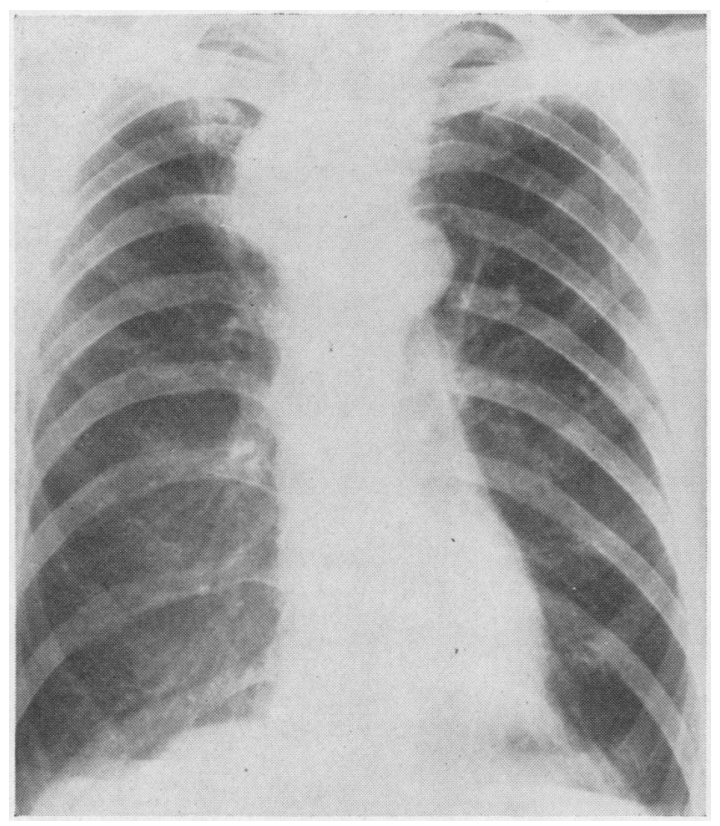

Fig. 10.-Malignant chromaffinoma.

Case L.4199.-A man of 50 years complained of weight loss for 18 months and of food sticking behind the sternum. Fig. 10 shows the mass to the right of the upper oesophagus. Endoscopy confirmed tracheal and oesophageal displacement by an external tumour. At thoracotomy on February 16, 1950, the tumour was found lying above the azygos vein and involving the oesophageal wall. It was not removable. Biopsy was reported: "The tissue is part of a malignant tumour. The growth is well differentiated and has a structure similar to carotid body tumour or chromaffinoma and is quite unlike most bronchial or oesophageal tumours. There is considerable necrosis and the tumour appears to be growing rapidly." A course of radiotherapy gave initial improvement but death supervened on March 27, 1952. No necropsy could be obtained.

\section{Thymic Tumours}

The thymus gland is frequently visible radiographically in the first year of life. Such cases are not regarded as having tumours. Ellis, Kirklin, Hodgson, Woolner, and DuShane (1955) reported that the normal thymus was visible in the first month in nearly all children but was seldom seen after the age of 2 years.

Forty-seven true tumours of the thymus are included in the present series, 30 benign thymomata, five thymic cysts, and 12 malignant thymomata.

Thymic CYSTS.-These presented as mediastinal tumours on radiography and were not associated with myasthenia. The literature on thymic cysts was reviewed by Krech, Storey, and Umiker (1954).

Tнумоми.-The diagnosis of malignant characteristics in thymoma has been the subject of some disagreement among the pathologists on the panel of the Tumour Registry. Unless the majority favoured malignancy or the clinical course showed that the thymoma was malignant, they have been classified as benign thymoma. It is on this basis that it is asserted that malignant thymic tumours were not associated with myasthenia in this series. They usually presented with increasing dyspnoea as the tracheal lumen became narrowed.

Six of the benign thymomata were associated with myasthenia, or $20 \%$. Seybold, McDonald, Clagett, and Good (1950) had 45 thymoma cases of which 34 or $75.6 \%$ had myasthenia. They also report that $15 \%$ of their myasthenia cases had a thymic tumour. In Liverpool in the 15 years covered by this review, the incidence of thymic tumour in myasthenia gravis has been $22 \%$.

\section{THYROID TUMOURS}

The Tumour Registry cases are thought to be unrepresentative and are not discussed in the ensuing paragraphs except where stated.

LIVERPOOL CASES. - Thirty tumours were benign and six malignant. In 19 cases the patients were males and in 17 females. Fifteen tumours arose from the left lobe, 17 from the right lobe, two from both lobes, and two were ectopic in the chest and unconnected with the thyroid gland in the neck, one on each side.

Clinical Features. - Three benign and two malignant cases had objective evidence of thyrotoxicosis. Nine benign and two malignant cases had a palpable goitre in the neck. One patient with a benign tumour was aged 20 years, 11 patients with benign and one with malignant tumours were aged 30-49 years, and 18 patients with benign and five with malignant tumours were over 50 years old. Four benign cases had no symptoms and were found to have an abnormal shadow on routine radiography. All other cases had symptoms, usually dyspnoea, cough, sometimes stridor or dysphagia.

Surgical Removal. - Twenty-two thyroid "adenomas" which were benign were removed through a cervical incision, the others requiring thoracotomy also or alone. Of these, in six there was a pedicle from the neck and in two the gland was ectopic with a local blood supply. 

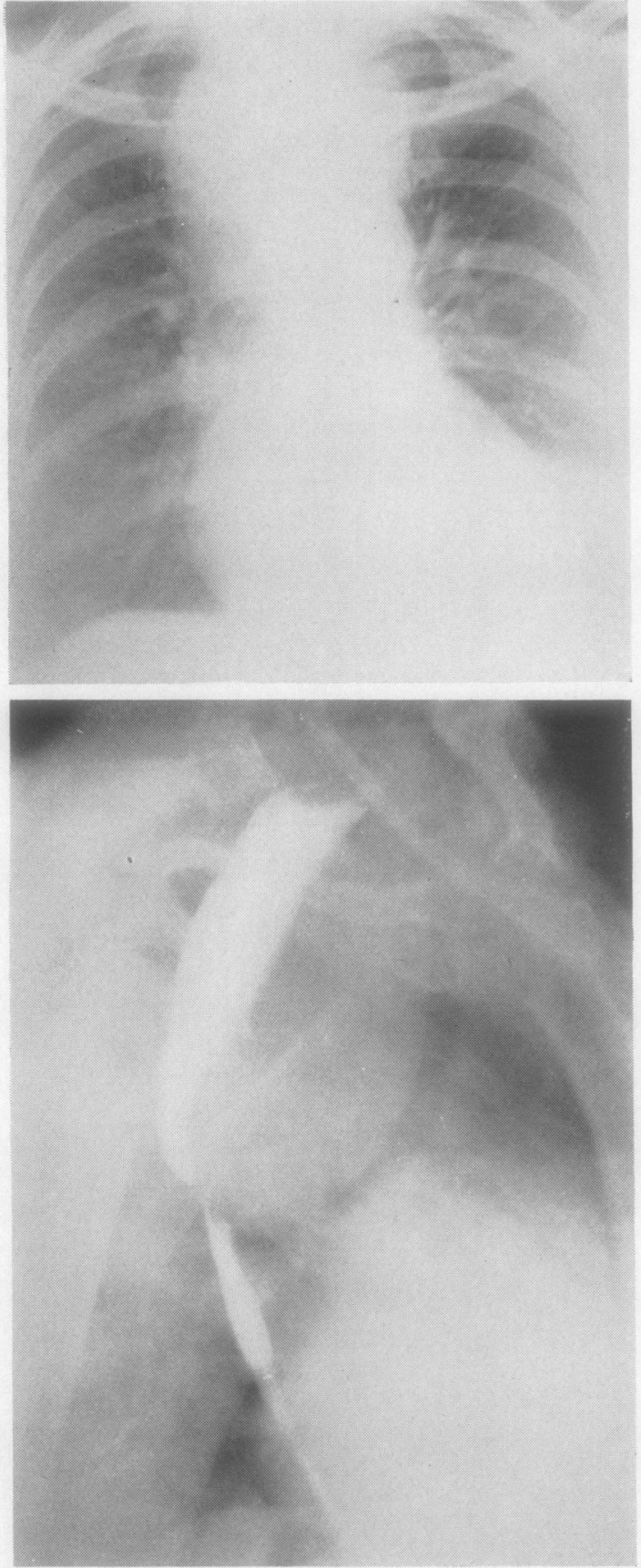

FIG. 11.-Posterior mediastinal thyroid tumour. Postero-anterior and oblique views while patient was swallowing barium showing the tumour lying between the oesophagus and trachea.

In the malignant cases, two had neck incisions with partial removal to relieve dyspnoea, and the others had thoracotomy or a combined approach.
Posterior Mediastinal Thyroid Tumours.Of the 36 cases, seven benign and one malignant were situated posterior to the trachea and lateral or posterior to the oesophagus. Sweet (1949) had six posterior cases out of 57 . He considered that they were extensions from the postero-lateral aspect of the gland and not from the inferior pole. He recommended removal by the chest rather than the neck. Crohn and Kobak (1951) reported one case, Burnett and others (1952) one case, and Hurwitz and Skorneck (1956) two cases; all of these tumours were removed through the chest. Of the eight cases treated at Liverpool, two tumours were removed by the neck, two by a combined approach, and four by thoracotomy. In the Tumour Registry series, there are three posterior mediastinal thyroid tumours, one removed by the neck and two by thoracotomy. It is noteworthy that posterior mediastinal thyroid tumours are about equally frequent on each side of the chest. Fig. 11 shows one such case.

\section{Parathyroid Tumours}

One case is included in the Tumour Registry. The patient was a woman, a mental patient of 60 , with typical hyperparathyroidism. The tumour was removed and proved to be a benign parathyroid adenoma.

\section{Mesenchymal Tumours}

LEIOMYOMA.-One case occurred, presenting as a large, almost circular, opacity in the left parapericardial region, rather anterior when compared with the case of Rajasingham and Cooray (1954). It is possible that this tumour was really a fibroma.

Fibroma.-These may grow to a large size and appear anywhere in the chest. Fibroma of the mediastinum is, therefore, merely a particular example. Giant fibroma of the pleura has not been included in this series. Schlumberger (1951) found that fibroma of the mediastinum was usually anterior and fibrosarcoma paravertebral in position. Four cases of fibroma occurred in this series, one posterior and three anterior.

Fibrosarcoma.-There were two cases, one anterior and one posterior. The anterior one arose from the pericardium.

SARcoma.-One case arose in the posterior inferior mediastinum. The panel of pathologists were not in agreement about the histological picture apart from regarding it as a primary malignant connective tissue tumour. 

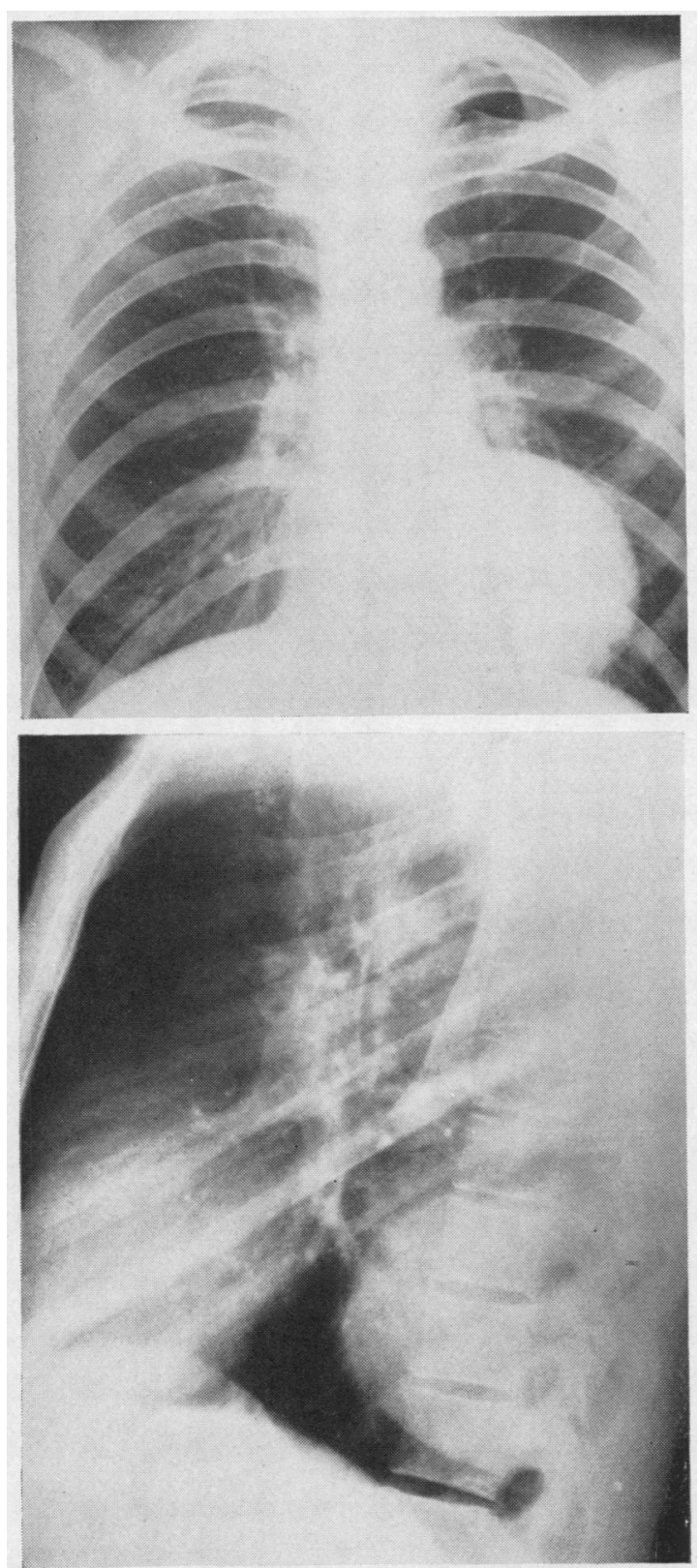

FIG. 12.-Haemangioma of the mediastinum.

ChondRomyxoma.-This tumour occurred once, in a man of 57 years treated in 1941. The tumour lay in the anterior mediastinum and did not apparently arise from the sternum. It subsequently recurred and was similar to that of Schwinger and Hemley (1953) which was a rapidly fatal chondromyxosarcoma of the anterior mediastinum. Heuer and Andrus (1940) reported a chondromyxoma of the posterior mediastinum.

Haemangioma.-Ellis, Kirklin, and Woolner (1955) reported one haemangioma of the mediastinum and added 18 from the literature. Valle (1954) also had one case and found 24 reported by other authors. Dixon and Laird (1956) had a case which they thought to be the first successfully operated on in Great Britain, the operation being in May, 1954. The case cited below was operated upon in Liverpool on July 27, 1953. Balbaa and Chesterman (1957) reviewed 66 cases and added three more.

Case L.8208.-A man aged 39 years was found on routine radiography to have a rounded shadow in the left lower paravertebral region (Fig. 12). There were no bony changes. The tumour, which was near the sympathetic chain, was removed on July 27, 1953. Dr. Whitwell reported: "A rounded solid tumour covered by shiny membrane. The cut surface is fleshy and white, and it measures $8 \times 7 \mathrm{~cm}$. across. Contained in the tumour are sharply demarcated red soft areas, the largest being $3 \times 2.5 \mathrm{~cm}$. across. Microscopically, it is rather cellular, being composed of lymphocytes, fibroblasts, and some reticulum cells, with interlacing blood capillaries and a fine intercellular fibrosis. Pseudogerminal follicles are present and some eosinophils. Areas of necrosis appear to be related to large thrombosed blood vessels which have a haemangiomatous appearance. It appears to be entirely benign."

The other case in the Tumour Registry was a girl of 16 years who had had a cystic hygroma removed from the left side of the neck at the age of 8 . She was found on routine radiography to have an opacity in the left anterior mediastinum. The tumour was removed and proved to be a haemangioma.

It seems not unlikely that haemangioma is really a developmental abnormality (hamartoma) rather than a true tumour.

Lipoma.-Keeley, Gumbiner, Guzauskus, and Rooney (1953) reviewed 57 cases of intrathoracic lipoma, classifying them as entirely intrathoracic or partly extrathoracic with an intervening narrow portion. Their own case took the form of a fatty blanket over the pericardium. Three cases occurred in the present series, two tumours being in contact with the pericardium and the other was in the upper anterior mediastinum.

\section{LYMPHOMAS}

It has been pointed out already that some authors exclude these from their total series, whereas Heuer and Andrus (1940) found 32\% of mediastinal tumours to be lymphomas. Key (1954) reported 101 mediastinal tumours, of which 44 were lymphomas. Table VIII shows the distri- 


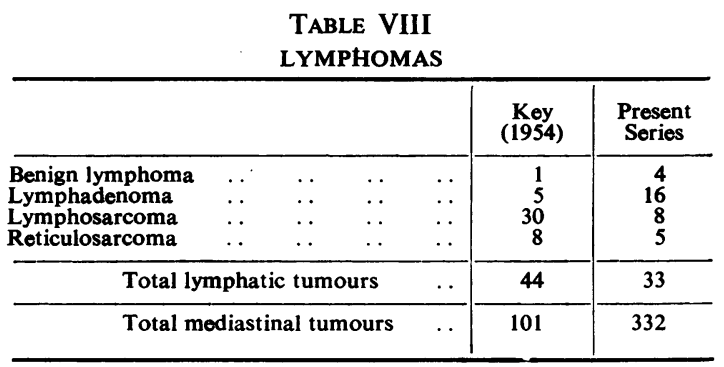

bution of his series and the present one. The malignant lymphomas presented first in the mediastinum, hence their inclusion in this series. Where the course of the disease was followed, it did not differ from malignant lymphoma presenting first elsewhere in the reticulo-endothelial system.

Benign LyMPHOMA.-Three patients presented with a well-defined round opacity in the mid-zone near the hilum of the right (two cases) or left lung. Two were males aged 21 and 27 years and one a female aged 50 years. When the tumour was explored, it was found in each case to be in the mediastinum at the lung root and was easily removed. Histologically, the tumour mass consisted entirely of normal lymphatic tissue, although it was far larger than any normal lymph node. Fig. 13 shows one such case. The fourth benign lymphoma was quite different.

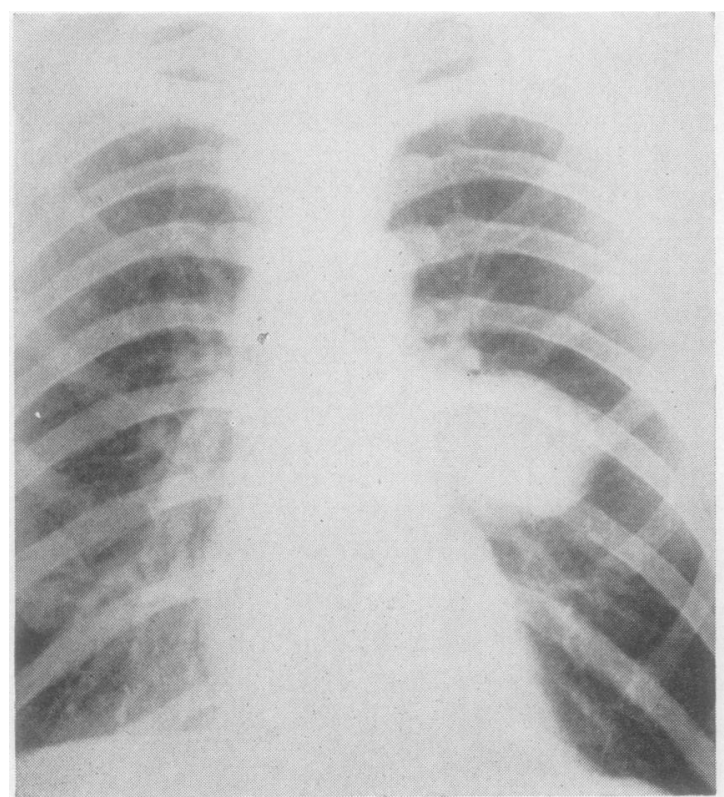

Fig. 13.-Benign lymphoma of the modiastinum.

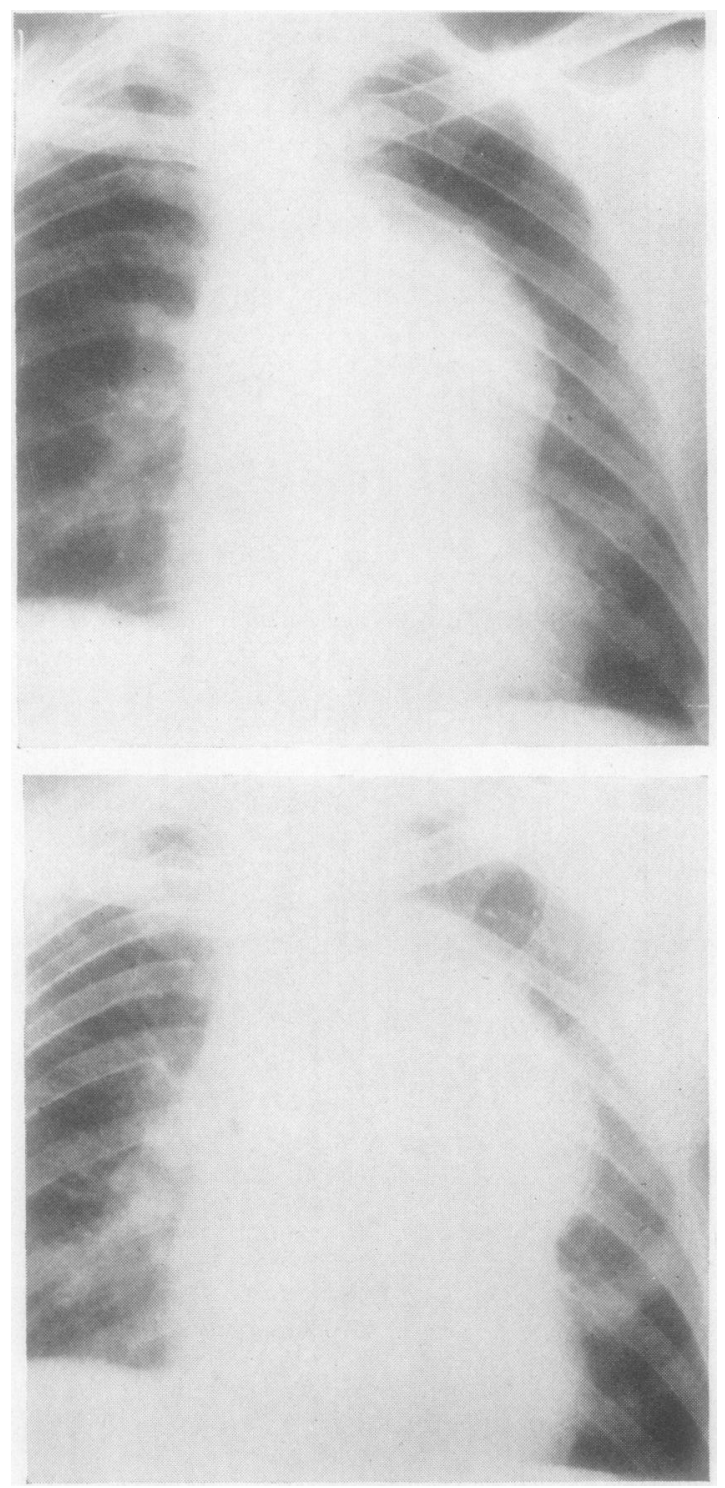

FIG. 14.-Superior mediastinal tumour (benign lymphoma) showing an increase in size between May 26, 1954, and June 17, 1957.

Case L.10110. - A man aged 51 years complained of aching substernal pain of six months' duration. He had no cough or dyspnoea. Thoracoscopy revealed a non-pulsatile shadow in the anterior mediastinum. At bronchoscopy the trachea was seen to be pushed forward by a mass posteriorly. There was no lymphatic enlargement elsewhere and the liver and spleen were normal. Left thoracotomy on December 20, 1954, disclosed a nodular mass which surrounded the aorta and other mediastinal structures. Biopsy of the mass showed that it was normal lymphatic tissue. No 
further treatment was given and he remains clinically unchanged. Fig. 14 shows that the shadow increased in size between May 26, 1954, and June 17, 1957. There is nevertheless no clinical deterioration. The diagnosis of benign lymphoma is based on the histological findings and clinical course.

\section{SUMMARY}

A series of 332 tumours and cysts of the mediastinum is reported and compared with recent published series. The cases are classified by age, sex, site, and histological type.

Tumours and cysts of developmental origin are grouped by their tissues of origin. Hypotheses are put forward to explain the occurrence of teratoid tumours in the posterior mediastinum and the association of foregut cysts with vertebral anomalies. The most unusual cases are cited in greater detail.

Neurogenic tumours are classified and the rare paragangliomas are described further. The thymic, thyroid, and parathyroid tumours are detailed and attention is drawn to the not uncommon posterior mediastinal goitres. Mesenchymal tumours are classified by histological type and a case of haemangioma is reported at greater length.

In the case of lymphomas, particular mention is made of the benign type, with illustrations.

My thanks are due to Mr. F. Ronald Edwards for suggesting this investigation and for his help and advice; to him, Mr. B. J. Bickford, Mr. L. J. Temple, and $\mathrm{Mr}$. J. K. B. Waddington for allowing me to report their cases; to Dr. F. Whitwell for much helpful advice and for most of the pathological reports on Liverpool cases; to Professor Harrison, of the Department of Anatomy, Liverpool University, for valuable suggestions on embryological problems; to the Society of Thoracic Surgeons of Great Britain and Ireland for allowing me to use the material of the Tumour Registry, and to Dr. J. W. Clegg and Miss F. Smith of the Department of Pathology, Brompton Hospital, for assistance in making the Tumour Registry files available to me; and to Mrs. D. Anthony for secretarial help. Miss B. Duckworth drew the diagrams. The Tumour Registry Panel of
Pathologists at the relevant period included Professor W. G. Barnard, Professor A. C. P. Campbell, Dr. J. W. Clegg, Dr. K. F. W. Hinson, Dr. F. Whitwell, and Professor R. A. Willis.

I must emphasize that any controversial views expressed are my own and not necessarily those of any of the foregoing persons.

\section{REFERENCES}

Ackerman, L. V., and Taylor, F. H. (1951). Cancer, 4, 669. Balbaa, A., and Chesterman, J. T. (1957). Brit. J. Surg., 44, 545. Bickford, B. J. (1949). Ibid., 36, 410.

Blades, C. B. (1946). Ann. Surg., 123, 749.

Brines, O. A., and Jennings, E. R. (1948). Amer. J. Path., 24, 1167.

Burnett, W. E., Rosemond, G. P., and Bucher, R. M. (1952). Surg. Clin. N. Amer., 32, 1673.

Childress, M. E., Baker, C. P., and Samson, P. C. (1956). J. thorac. Surg., 31, 338.

Crohn, N. N., and Kobak, M. W. (1951). Amer. J. Surg., 82, 283.

Dixon. W. M., and Laird, R. (1956). Thorax, 11, 45.

Duncan, D. K., and McDonald, J. R. (1951). Amer. J. clin. Path., 21, 515

Ellis, F. H., and DuShane, J. W. (1956). Amer. Rev. Tuberc., 74, 940. Kirklin, J. W., Hodgson, J. R., Woolner, L. B., and DuShane, J. W. (1955). Surg. Gynec. Obstet., 100, 532.

$1-$ and Woolner, L. B. (1955). J. thorac. Surg., 30, 181

Fallon, M., Gordon, A. R. G., and Lendrum, A. C. (1954). Brit. J. Surg., 41, 520.

Godwin, J. T., Watson, W. L., Pool, J. L., Cahan, W. G., and Nardiello, V. A. (1950). J. thorac. Surg., 20, 169.

Gross, R. E., and Hurwitt, E. S. (1948). Surg. Gynec. Obstet., 87, 599.

Harrington, S. W. (1949). Postgrad. Med., 6, 6.

Heuer, G. J., and Andrus, W. D. (1940). Amer. J. Surg., 50, 143.

Hirschfeld, K. (1951). Aust. N.Z. J. Surg., 21, 27 and 81.

Hurwitz, A., and Skorneck, A. B. (1956). Surgery, 39, 991.

Keeley, J. L., Gumbiner, S. H., Guzauskus, A. C., and Rooney, J. A. (1953). J. thorac. Surg., 25, 316.

Keith, A. (1948). Human Embryology and Morphology, 6th ed. Arnold, London.

Kent, E. M., Blades, B., Valle, A. R., and Graham, E. A. (1944). $J$. thorac. Surg., 13, 116.

Key, J. A. (1954). Surg. Clin. N. Amer., 34, 959

Krech, W. G., Storey, C. F., and Umiker, W. C. (1954). J. thorac Surg., 27, 477.

Lillie, W. I., McDonald, J. R., and Clagett, O. T. (1950). Ibid., $20,494$.

Maier, H. C. (1948), Ann. Surg., 127, 476.

Mazer, M. L. (1946). Amer. J. Roentgenol., 55, 27.

McDonald, O. G., Aufderheide, A. C., and Fuller, J. (1954). Ann. Surg., $140,254$.

Miller, J. W. (1924). Zbl. allg. Path. path. Anat., 35, 85. Cited by Schlumberger, 1951.

Olenik, J. L., and Tandatnick, J. W. (1946). Amer. J. Dis. Child.,

Peabody, J. W., Strug, L. H., and Rives, J. D. (1954). A.M.A. Arch. intern. Med., 93, 875 .

Rajasingham, A.S., and Cooray, G. H. (1954). Brit. J. Surg., 41, 446.

Ringertz, N., and Lidholm, S. O. (1956). J. thorac. Surg., 31, 458.

Rusby, N. L. (1944). Ibid., 13, 169.

Sabiston, D. C and Scott, H.W. (1952). Ann. Surg., 136, 777.

Sale, T. A. (1953). Arch. Dis. Childh., 28, 325.

Schlumberger, H. G. (1951). Atlas of Tumor Pathology, Section V, Fascicle 18. Armod Forces Institute of Pathology, Washington.

Schwinger, A., and Hemley, S. D. (1953). Dis. Chest, 24, 670.

Seybold, W. D., McDonald, J. R., Clagett, O. T., and Good, C. A. (1950). J. thorac. Surg., 20, 195

Shaw, K. M., and Kennedy, J. D. (1956). Thorax, 11, 57.

Sweet, R. H. (1949). Surg. Gynec. Obstet., 89, 57.

Valle, A. R. (1954). Ann. Surg., 140, 771.

Vanpeperstraete, F. (1956). Acta chir. belg., 55, 624. 